
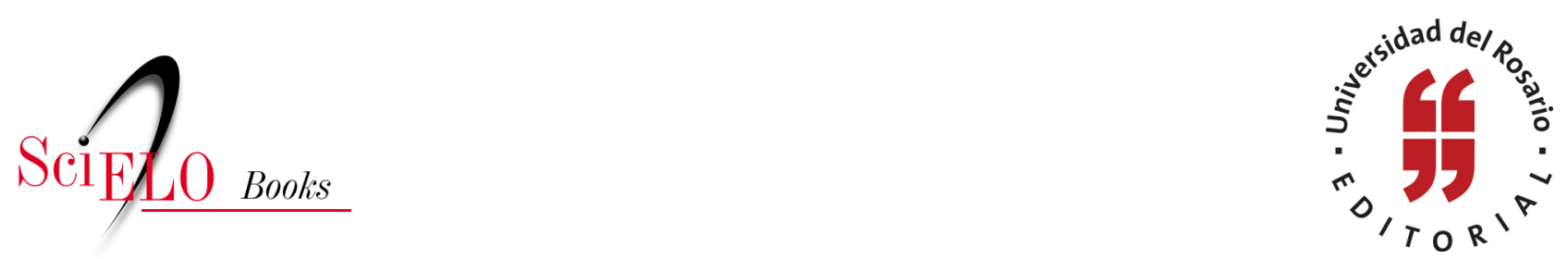

\title{
19. ¿Es la Biblia tan solo un buen libro?
}

\author{
César Augusto Tapias Hernández
}

\section{SciELO Books / SciELO Livros / SciELO Libros}

TAPIAS HERNÁNDEZ, C.A. ¿Es la Biblia tan solo un buen libro? In: Historias de familia: Etnografía delirante sobre el amor, la violencia y las drogas [online]. Bogotá: Editorial Universidad del Rosario, 2014, pp. 81-84. Textos de ciencias humanas collection. ISBN: 978-958-738-543-4.

https://doi.org/10.7476/9789587385434.0020.

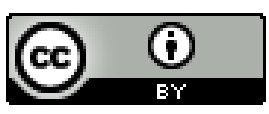

All the contents of this work, except where otherwise noted, is licensed under a Creative Commons Attribution 4.0 International license.

Todo o conteúdo deste trabalho, exceto quando houver ressalva, é publicado sob a licença Creative Commons Atribição 4.0.

Todo el contenido de esta obra, excepto donde se indique lo contrario, está bajo licencia de la licencia $\underline{\text { Creative }}$ Commons Reconocimento 4.0 . 


\title{
19. ¿Es la Biblia tan solo un buen libro?
}

\author{
Hemos existido, dice nuestra leyenda; de algunos deseos nuestros \\ nació esta ciudad. Luchamos contra fuerzas hostiles y un dia, \\ enflaquecidos, nuestros brazos dejaron caer las riendas. \\ Michel Houellebecq, El mundo como supermercado
}

Escena 1. Exterior/día/un mirador del pueblo. Ante la cámara, Gabriel Fernández (grabando. Acción):

- Un saludito desde aquí para todos mis paisanos de Titiribí, Antioquia. Pa' que ruede este casete allá en Bolivia y en los Estados Unidos... y conozcan el pueblo. Un pueblo muy bonito donde nacimos todos los Fernández que, aunque estén lejos (no lo olviden), vuelvan como nosotros estamos volviendo en esta excursión EXTRAORDINARIA..., porque fue aquí donde nos conocimos todos, donde nos tomamos la primera aguapanelita, montamos a caballo y oímos la primera misita.

Corte

Se trata de comentario en in (o frente a la pantalla) del tío Gabrielito, ante la cámara que recobraba imágenes para la posterioridad mientras se respiraba cierta nostalgia. Volviendo al pueblo donde nacieron todos los de la familia Fernández Quiroz (la familia de mi mamá) no solo encontramos calles, cafés y casas con historias; la cabeza se puso a recordar, y se recobraron emociones, y se convocaron sensaciones: la tía Carmen buscaba "sitio viejo", el lugar donde se fundó el pueblo. Rubiela quería pillarse de lejos el cementerio como adivinando ante un mapa, y Gildardo queriendo ver a "cañahuate", un primo suyo... La cámara desde el microbús en que viajamos, haciendo panorámicas del pueblo aún en la distancia, y con su lente metiéndose en casas ajenas: las que hay por toda la carretera. Son casas de baños afuera, o separados de las casas, de muchas ventanas, humo azul de la cocina, perros braveros a la entrada de algún zaguán... Y el tío Gabriel acompañado de "la 
mona" (su mujer por muchos años) mirando y mirando el monte trazando imaginariamente los caminos, caminos con los que hace poco se encontró de nuevo...

-Fue una vez con Iván. Nos quedamos casi una semana por todo este monte andando...

Escena 2. Transición de varios días Exterior/Día-Noche/campos entre Titiribí, Bolombolo...

Por la llanura, como Quijote y Sancho arrojados contra el viento, Gabrielito e Iván a caballo por esos campos entre Titiribí, Bolombolo y algún otro lugar reinventando rutas, viejos caminos, rehaciendo esperanzas, recobrando sueños y hasta viejos olores: el tiempo como una mariposa deseando ser oruga otra vez. Inocente y terca la mariposa esa, tratando, tratando, y como ya no hay seda que la cubra, se enrolla en sus alas: lo que le queda, pétalos de flor que vuela, abrazo acogedor que a veces se tiene que dar uno mismo: el tío Gabriel alojado en sus recuerdos habla como cantando, siendo tierno en el relato de un tiempo tierno y duro a la vez.

Por disolvencia: una imagen se funde con otra.

Escena 3. Exterior/Día/un mirador del pueblo. De nuevo ante la cámara Gabriel Fernández (grabando. Acción):

- Para poder que nos llevaran al pueblo el día domingo, desde el día sábado nos mandaban a bañar, nos daban jaboncito bueno: JABONCITO DE OLOR; por eso me acuerdo de la canción: "Mañana es domingo / deja que me lave / despacito, mamá / con jabón de olor...”. Nos bañábamos el sábado pa’ bajar el domingo al pueblo. Eran tres o cuatro horas de camino para llegar, entonces teníamos que salir temprano y llevábamos huevitos para vender en la cafetería y con eso nos tomábamos el desayunito en la panadería.

Corte

El tío Gabriel me sorprendió con su erudición ante cámara: frescura total, amplio dominio, y por todo lo mucho que tenía para hablar, sobre todo por eso. Y resulta notorio porque él habla poco en una reunión familiar, siempre es "La Mona", su mujer, la responsable de hablar... "La Mona" es una mujer a quien le sobran las sonrisas. Y habla poco el tío porque poco es cruzable con los demás, salvo recordar o recochar. Mi tío Gabriel es el único evangélico en una familia tradicionalmente católica. Y dice que se metió a eso dado un claro interés por las sagradas escrituras que lo acompaña desde muy joven. Y descubrió con el tiempo que la religión católica no tiene como meta el principio del cristiano: "Vivir según enseña la Biblia". Y para ilustrarse, me explica por ejemplo la idea que circula frente al infierno: “... es una invención de los hombres, sin duda”. 
Escena 4. Exterior/Tarde/Patio de la casa de Gabrielito

Dándome la espalda, sin pretender dejar ahí el tema, Gabrielito arregla las jaulitas de sus pájaros: pericos y canarios de todos los colores que adornan su patio con sus colores y cantos...

—¿Qué padre pone las manos de sus hijos sobre el fogón? Es falso todo aquello de un lugar donde la gente se quema y padece...

- Pero debe haber un sitio para los lamentos...

Pienso, por ejemplo, y se me vienen a la mente algunos dibujos de La divina comedia, y los sollozos del poeta, la creación de un católico militante. Allí, se narra cómo las almas esperan la redención o su segunda muerte. A su manera, el tío también se queja, o expone como ejemplo algo que puede marcar la diferencia entre los rituales católicos y las creencias por las que él se ha decidido. Las diferencias pueden notarse, pues como si se tratara de un plato servido a la mesa, un plato al alcance del paladar, la Biblia por lo menos hoy se pueden probar.... Antes a nadie le era permitido leerla. La Iglesia católica no lo convenía... ¿ ¿por qué? Se pregunta el tío aun cuando hablamos de hace muchísimos años...

En el año 777 de nuestra era, los tiempos de Carlo Magno, el unificador de la Europa cristiana, los sajones eran vistos como paganos a los que se tenía que convertir mediante el bautismo... sin previo aviso, sin opción a preguntar de qué se trata eso... Tomen. Háganse creyentes... Pero mi tío, que fue criado en un hogar católico, preso quizás de la herencia y la tradición, alcanzó a su manera el conocimiento requerido, aquello que le antojaba: la curiosidad después de haber sido la ñaña de mamita Laura, una matrona muy rezandera... Ni eso, ni el tener una hermana monja en casa, pararon a Gabrielito en su búsqueda. Carlo Magno bien tenía en sus manos la fuerza y la creencia de gozar del beneplácito de Dios. Era fuerte y hacía convertir a los paganos, en nombre de Dios. En la familia Fernández solo habría un poco de indiferencia. Quizás se creía, a lo mejor se cree todavía, que los equivocados son los de otra religión y que Dios a ellos no los acompaña, ¿̇o se trata de otro Dios?

- Qué una misa por mi mamá, que una novena por aquel, y yo que no. Yo a eso no voy... El muerto, muerto está y nada puede hacer por nosotros.

Retoma. Escena 4. Exterior/tarde/patio de la casas de Gabrielito.

-A mí me gusta atender la visita en el patio, como en las casas de antes. Aquí me distraigo con los pajaritos, quizás sea porque ya tenemos el don de preferir cosas tranquilas, así como le pintan a uno el paraíso...

El tío Gabriel tiene 52 años. Desde hace unos 30 es cobrador en el Hospital San Vicente de Paul. Le toca ir a las aseguradoras y en medio de mucho papeleo hacer 
efectivo los cobros... Dice que lo pusieron Gabriel, recordando a Gabriel Ángel, uno más de la casa que no alcanzó a ser, murió... Está casado con Amparo o "La Mona" como casi todos le dicen, una mujer a quien conoció a través de otra mona, la hermana de Amparo, de quien Gabrielito era compañero en un colegio nocturno:

- Un día fuimos a ver un partido de fútbol por allá en Bolivariana y la conocí porque la hermana la llevó. Ellas vivían por donde hoy es el Éxito de San Antonio, en unas casitas que había por ahí...

Sin embargo, insistía mi tío en hablarme de la Biblia. Como a muchas, no le dije a él por qué de tanta preguntadera. La razón de mi visita fue prestarle el video que se logró en la excursión extraordinaria a Titiribí. Creyó él que mi inquietud por su vida iba tras otras cosas...

- ¿Por qué recordaste que en Titiribí fuiste a la primera misa, siendo hoy otro tipo de creyente?

- Porque antes no tenía uso de razón. Cuando adulto me busqué lo mío y lo encontré. Me siento bien. Fue mi decisión. Lo que antes era una tradición en la que nunca te pedían consentimiento: que los papás lo llevaran a uno a oír misa... $\mathrm{Y}$ eso es algo que hace parte de uno.

- ¿Y los abuelos dijeron algo cuando creciste y te cambiaste?

- Habrán quedado desconsolados, pero qué se va a hacer, sobre todo mi mamá. Luego de que yo la acompañara a todas las misas, de que le hiciera los altares y, en fin, todo aquello...pero vea, mijo, léase esta revistica para que se oriente más y luego volvemos y hablamos. Se llama ¿Es la Biblia tan solo un buen libro? A mí me gustó mucho. ¡Léasela! A ver si usted también se ilumina... 